\title{
Estudio de las compensaciones económicas sobre sentencias contra obstetras y ginecólogos en España (1987-2013).
}

García Ruiz, Nicolás, Santiago Sáez, Andrés, Albarrán Juan, María Elena, Labajo González, Elena y Perea Pérez, Bernardo.

Cita:

García Ruiz, Nicolás, Santiago Sáez, Andrés, Albarrán Juan, María Elena, Labajo González, Elena y Perea Pérez, Bernardo (2017). Estudio de las compensaciones económicas sobre sentencias contra obstetras y ginecólogos en España (1987-2013). Revista Española de Medicina Legal, 43 (2), 64-69.

Dirección estable: https://www.aacademica.org/elenalabajogonzalez/33 ARK: https://n2t.net/ark:/13683/pcQr/rwv

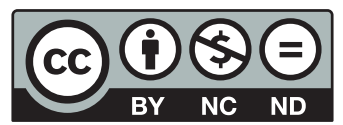




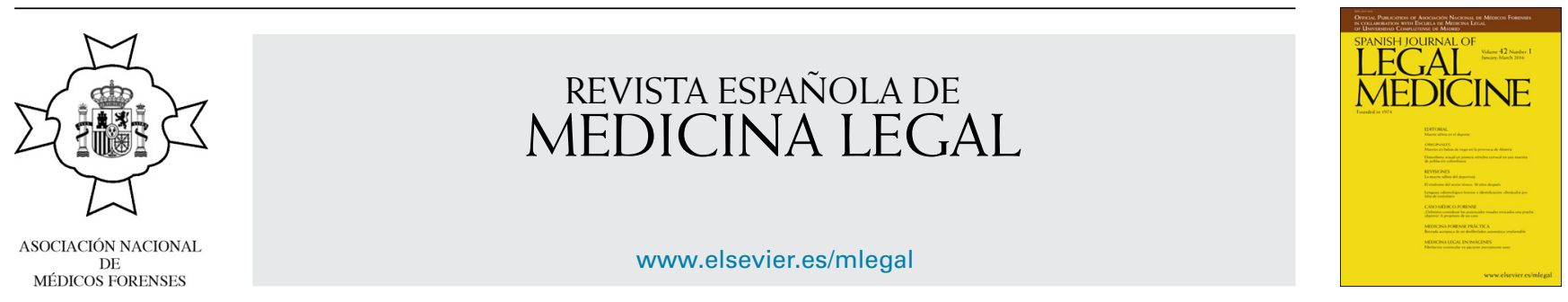

ORIGINAL ARTICLE

\title{
Study of financial compensation in rulings against obstetricians and gynaecologists in Spain $(1987-2013)^{\text {is }}$
}

\author{
Nicolás García-Ruiz ${ }^{\mathrm{a}}$, Andrés Santiago-Sáez ${ }^{\mathrm{b}, \mathrm{c}, *}$, María Elena Albarrán-Juann ${ }^{\mathrm{b}}$, \\ Elena Labajo-González ${ }^{\mathrm{b}}$, Bernardo Perea-Pérez ${ }^{\mathrm{b}}$
}

a Servicio de Obstetricia y Ginecología, Hospital El Escorial, Madrid, Spain
b Escuela de Medicina Legal y Forense, Universidad Complutense de Madrid, Madrid, Spain
c Servicio de Medicina Legal, Hospital Clínico San Carlos, Madrid, Spain

Received 3 November 2016; accepted 29 November 2016

Available online 12 May 2017

\author{
KEYWORDS \\ Compensation; \\ Gynaecologist \\ convictions; \\ Claims; \\ Obstetrics litigation; \\ Medical liability; \\ Medical malpractice
}

\begin{abstract}
Introduction: Malpractice payouts occupy an important place in Obstetrics and Gynaecology. We analysed a long period (1987-2013) of court sentences focusing on compensation amount and the way compensation has changed. In Spain there are not many economic analyses on Obstetrics and Gynaecology, specifically on the main adverse events that lead to catastrophic payouts. Material and methods: A retrospective analysis of a legal database on court sentences in civil and administrative litigation against obstetricians and gynaecologists during the study period was performed. The adverse event under examination, the year of the ruling, and the payouts for malpractice were the variables analysed. Statistical analysis was performed using SPSS Statistics 19.0, F-distribution and normal distribution tables as well as the Student's $t$-test to compare differences between groups.

Results: We recovered 431 cases, 244 of which resulted in a conviction (56.6\%). Obstetrics involved the highest payouts $(p=0.01)$ and a $57.5 \%$ chance of being convicted. The accusations with the highest payouts involved foetal death or foetal injury, which were the most common cause of payouts exceeding $€ 300,000$. Overall, 78.7\% (193) of convictions involved a payout below $€ 300,000$ and the mean, median and maximum payouts increased steadily during the study period.

Conclusions: Obstetric claims and foetal-related injury involve the highest payouts, with an increasing trend. Catastrophic payouts are common.

(C) 2016 Asociación Nacional de Médicos Forenses. Published by Elsevier España, S.L.U. All rights reserved.
\end{abstract}

DOI of original article: http://dx.doi.org/10.1016/j.reml.2016.11.003

is Please cite this article as: García-Ruiz N, Santiago-Sáez A, Albarrán-Juan ME, Labajo-González E, Perea-Pérez B. Estudio de las compensaciones económicas sobre sentencias contra obstetras y ginecólogos en España (1987-2013). Rev Esp Med Legal. 2017;43:64-69.

* Corresponding author.

E-mail address: ansantia@ucm.es (A. Santiago-Sáez). 


\section{PALABRAS CLAVE \\ Indemnizaciones; \\ Condenas a \\ ginecólogos; \\ Demandas; \\ Judicialización en \\ obstetricia; \\ Responsabilidad \\ médica; \\ Negligencias médicas}

\section{Estudio de las compensaciones económicas sobre sentencias contra obstetras y ginecólogos en España (1987-2013)}

\begin{abstract}
Resumen
Introducción: En indemnizaciones por mala praxis, la obstetricia y la ginecología ocupa un lugar destacado. Analizamos las sentencias de un largo periodo (1987-2013) centrándonos en la cuantía de las indemnizaciones y su evolución. En España existen pocos análisis económicos de esta especialidad y específicamente que muestren aquellos eventos adversos que soportan las indemnizaciones más elevadas.

Material y métodos: Se trata de un análisis retrospectivo de las sentencias judiciales en las vías civil y contencioso-administrativa, contra obstetras y ginecólogos tomadas de bases de datos jurídicas en el periodo de estudio. Las variables consideradas han sido las indemnizaciones en los casos de condena, el evento adverso juzgado y el año de la sentencia. El software estadístico SPSS 19.0 permitió obtener tablas de distribución de Fisher, de normalidad y el t test para comparación de diferencias entre grupos.

Resultados: De 431 casos, 244 terminaron en condena (56,6\%). La obstetricia soportó las indemnizaciones más elevadas (p, 0,01) y una probabilidad de ser condenado del $57.5 \%$. Los eventos relacionados con daño o muerte foetal presentaron las indemnizaciones más elevadas y fueron la causa más común entre las indemnizaciones, superiores a $300.000 €$. Globalmente, en el $78,7 \%$ (193) de los casos con condena, la cantidad fue inferior a $300.000 €$. Los máximos, así como la media y la mediana de las indemnizaciones, fueron aumentando a lo largo del periodo de estudio.

Conclusiones: Las demandas en el entorno de la obstetricia y los daños relacionados con el feto soportan las indemnizaciones más elevadas, con tendencia a incrementarse. Las indemnizaciones extremas no son infrecuentes.

(c) 2016 Asociación Nacional de Médicos Forenses. Publicado por Elsevier España, S.L.U. Todos los derechos reservados.
\end{abstract}

\section{Introduction}

To prevent malpractice claims it is best to know the causes and to learn by analysing all the factors involved in possible errors. It is clear that in Spain and Europe, in general, there is less interest in deepening the analysis of complaints than in the Anglo-Saxon world, even though this knowledge would help to improve quality of care and patient safety. This knowledge could also lead to a decrease in costs for individuals and for the health system itself., ${ }^{1,2}$

Information on malpractice claims often comes from the media, which focus on claims with the highest compensation and most newsworthiness, and which, although caused by the most serious errors, represent a biased assessment, at times projecting insecurity about the system and thus contributing to an increase in health costs. ${ }^{3}$ Moreover, we are not aware of the real significance of the term "constant increase" in relation to "medical malpractice', which can range from problems in the management of waiting lists to complaints about medical errors, often forgetting about the result of the final judgement regarding the latter.

In Spain, one of the first analyses dates back to $1993 .{ }^{4}$ After assessing the health and judicial systems, taking into account the decisions of the Supreme Court of Spain, the analysis already refers to an increase in the number of claims, although other authors also using court data state that few of these claims lead to compensation. ${ }^{2,5}$
Regarding the current accident rate in our health system, a Catalan group the Legal Medicine Unit of the Official Medical Association of Barcelona is one of the most active. ${ }^{6}$ Our group has also made contributions of interest using data from judicial decisions. ${ }^{7,8}$ Although a biased view can be given in any case, we believe that, in the absence of other more reliable sources, the study of judicial rulings helps to prevent terminological corruption and render the analysis of the amounts of compensation to be included in the rulings themselves more reliable, with the exception of the Catalan health system.

In claims for damages arising from their activity, in Spain the fields of obstetrics and gynaecology take centre stage. ${ }^{7,9,10}$ Although it is doubtful whether this can be transferred to other settings, ${ }^{11}$ when the interest is focused on studying extreme (or catastrophic, as coined by some authors) amounts of compensation, ${ }^{9-13}$ it is customary to find this specialty in the top spot, irrespective of the country.

There seems to be a trend towards a progressive increase in compensation in our setting, excluding economic adjustments. ${ }^{11}$ In fact, Spanish legislative projects are in the works for calculating compensation for healthcare damages which refer to special cases, such as incidents involving individuals who were previously not sick. If they come into effect, they are unlikely to improve the situation in the field of obstetrics and gynaecology, which often deals with healthy people in situations, childbirth, where only a perfect result is expected. ${ }^{14,15}$ This paper conducts a specific 
analysis in this specialty and in our setting, focusing on the amounts of financial compensation, the evolution thereof, and the adverse events that rise to them, grouped as previously referred to in other publications. ${ }^{16}$ Decisions made by criminal courts have been excluded as we consider them a group with special connotations that have already been the object of a previous study. ${ }^{17}$

\section{Materials and method}

The paper mainly uses the Westlaw Aranzadi database of rulings, accessing the same from the School of Legal Medicine at the Complutense University of Madrid. All rulings in medical malpractice cases against gynaecologists have been collected across Spain, for medical procedures that occurred after 1987 with a ruling published before May 2013, and which reached at least a court of second instance or higher; i.e., Provincial Court, Superior Court of Justice, or Supreme Court. This database contains the full decisions. All were taken from civil and contentious-administrative procedures. The variables studied were the adverse effect of the claim, the year of the ruling and the final compensation.

The claims were grouped into 2 large groups-obstetrics and gynaecology-each with its own differentiation by events.

Statistical analysis was performed using the SPSS 19.0 statistical software, Fisher's exact test, normal distribution test and Student's $t$-test were used to compare the differences between groups, and the non-parametric Mann-Whitney test was used to compare independent samples. Cases were grouped by periods and ranges according to the amounts used by insurance companies in civil liability coverage for health professionals.

\section{Results}

The study includes 431 rulings, with 244 convictions and their corresponding compensation awards. In obstetrics the average award was $€ 271,573$, compared with $€ 63,678$ in gynaecology $(p, 0.01)$, with a maximum of $€ 1,627,213$ and $€ 850,000$ and a median of $€ 180,000$ and $€ 30,000$, respectively.

Fig. 1 shows the amounts grouped according to the most relevant and most common events. It can be seen that compensation for permanent brain damage is the most important in terms of maximum and average amounts, with up to $€ 20,000,000$ requested for compensation. Maximum compensation awarded was: $€ 1,627,213$ for permanent brain damage; $€ 750,000$ for errors in prenatal diagnosis; $€ 300,000$ for shoulder dystocia; $€ 250,000$ for foetal death; $€ 850,000$ for complications of hysterectomy; $€ 250,000$ for delays in diagnosing breast cancer; and $€ 180,000$ for curettage complications. The high compensation for complication of hysterectomy was due to pulmonary embolism, with cardiorespiratory arrest and recovery with brain damage.

Table 1 summarises the compensation awards according to the ranges used by many insurance companies to calculate premiums. Almost $80 \%$ were less than $€ 300,000$ and only $3.4 \%$ were more than $€ 900,000$.

Given the extensive period analysed, it has been divided into intervals to assess the evolution of compensation and

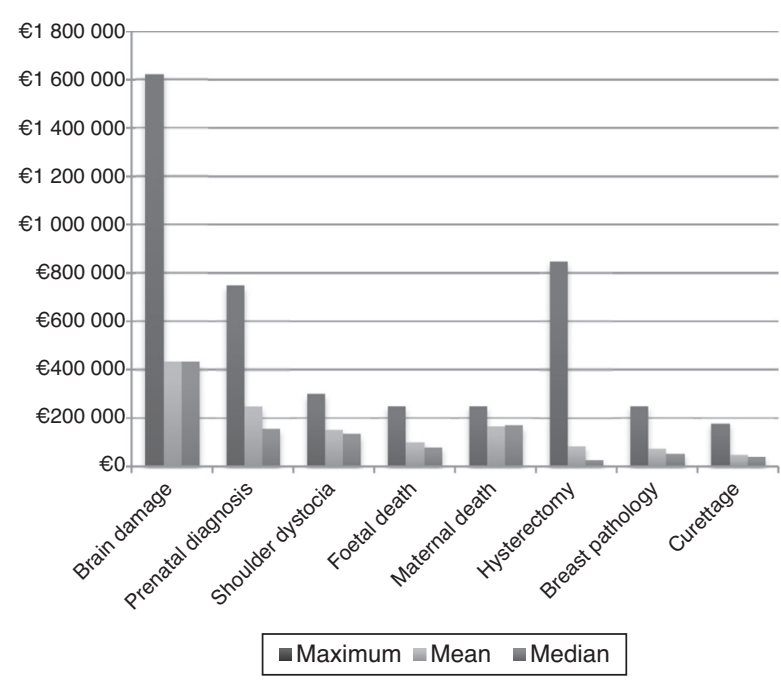

Figure 1 Amounts of compensation according to the grounds for the claim.

to facilitate comparison with other publications studying shorter periods. Fig. 2 shows that the trend is towards an increase in all parameters analysed: maximum compensation of $€ 480,000$ in the first period to $€ 1,627,000$ in the final one; an average of $€ 106,712$ in 1995-1999 to $€ 257,932$ in 2010-2013, and the same for medians of $€ 51,500$ to $€ 185,000$, respectively.

Replicating the design of other publications, data were collected from a similar range: 2004-2010. Of 104 compensation awards, 43 cases (41.34\%) exceeded $€ 200,000$, which would be the starting amount for what has been termed "catastrophic compensation". Of these, $€ 200,000-€ 399,999$ were awarded in 20 cases $(46.52 \%)$; $€ 400,000-€ 599,999$ in 7 cases $(16.27 \%)$, and over $€ 600,000$ in 16 cases $(37.2 \%)$. There are no gynaecology cases above $€ 300,000$, except for the aforementioned hysterectomy. Overall, all compensation awards are related to obstetric events, more specifically with childbirth and foetal damage

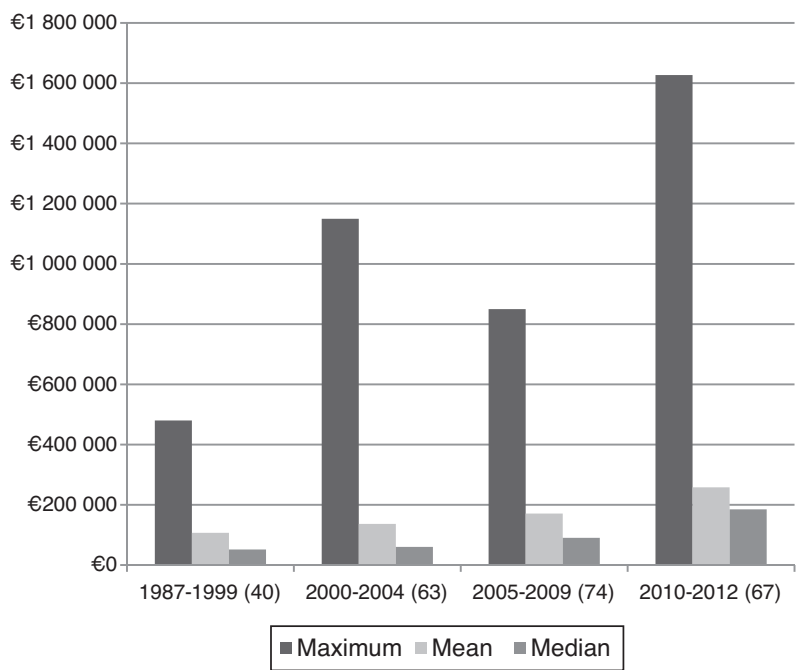

Figure 2 Amounts of compensation grouped by chronological intervals. 
Table 1 Compensation grouped by category.

\begin{tabular}{lccc}
\hline Compensation & Frequency & Percentage & Cumulative \\
\hline$<€ 300,000$ & 193 & 78.7 & 78.7 \\
$€ 300,001-€ 600,000$ & 31 & 12.6 & 91.4 \\
$€ 600,001-€ 900,000$ & 12 & 4.8 & 96.2 \\
$€ 900,001-€ 1,200,000$ & 8 & 3.1 & 99.2 \\
$>€ 1,200,001$ & 1 & 0.4 & 99.6 \\
Total & 244 & & 100 \\
\hline
\end{tabular}

or with errors in prenatal diagnosis, with $3(6.97 \%)$ cases exceeding $€ 900,000$.

\section{Discussion}

Complaints against physicians are the subject of widespread attention as they aim to reflect the safety and reliability of a health system, they have an impact on the behaviour of professionals towards what is known as defensive medicine, and they have impact on the media, among other issues.

The first point seems somewhat contradictory given that some authors believe that advances in therapeutics and technology and improved quality and safety standards have been accompanied by an increase in complaints against obstetricians and gynaecologists, ${ }^{18}$ contrary to expectations. Regarding obstetrics and gynaecology in developed countries, despite low maternal and infant mortality rates and the fact that safety in specialty departments is considered excellent, complaints against gynaecologists continue to rise, especially when compared with other specialties. ${ }^{19}$ The most common grounds leading to these claims, however, are the same throughout the world: neonatal encephalopathy, errors in prenatal diagnosis, shoulder dystocia, and errors in the screening of certain diseases. ${ }^{16}$

Another reason people focus on complaints against gynaecologists is their influence on changing attitudes in specific aspects of childbirth, which has led to an unjustified increase in the rate of Caesarean sections and low rates of assisted delivery. ${ }^{20,21}$ Recent publications even link this increase to a rise in insurance premiums covering professional liability, ${ }^{22}$ which would be justified by the increased number of claims and an increasing trend in the number of high, catastrophic (employing a term coined by other authors) compensation claims.9,10 This situation could worsen if health-specific projects come to fruition, ${ }^{14}$ which may reduce compensation for medical errors relating to sick patients but differentiate those relating to healthy patients, such as mother and foetus, and others within this specialty. In addition, the highest compensation awards are correlated with injured individuals of under one year of age, ${ }^{9,10}$ which is also the case here.

A particularity of our paper, which would justify the importance of obstetrics, is that it only collects judicial rulings from courts of second instance and higher, where it is assumed that the most serious cases are dealt with. It is also said that compensation is higher when the case is resolved in court. ${ }^{23,24}$ Our paper has not taken into account out-of-court settlements, about which we only have references from Catalonia, where the special features of medical insurance are resolved by out-of-court settlement in more than $70 \%$ of the cases in which physician responsibility is found, accounting for $25 \%$ of the total claims. ${ }^{25,26}$ We do not know how acceptance of these settlements is affected by the injury being caused to a sick or a healthy individual, which has been mentioned as a particular aspect in obstetrics and gynaecology. In any case, promoting this course should become the norm, with some authors already having done so. ${ }^{12,14}$

Compared with global data on the specialty, our paper aims for a more specific analysis, observing that diagnostic errors in some cancers are also important by frequency and by the amount of compensation, as has already been published. ${ }^{27}$ Despite the known heterogeneity in the causes of childhood cerebral palsy, and that few cases are exclusively related to severe hypoxia during childbirth, ${ }^{28-30}$ it seems appropriate to repeat that there are events that occur only at the time of childbirth and whose complications may result in this crippling disease. ${ }^{31,32}$ Claims that end in conviction for this latter complication include virtually all the "catastrophic" compensation awards and can be considered as a benchmark for the calculation of insurance premiums in obstetrics, which are among the highest. ${ }^{33}$

Extreme cases, which are the most high-profile ones, ${ }^{3}$ can create uncertainty regarding the system's safety by relating them to negligent $\mathrm{acts}^{34}$; however, these are rare cases and only account for a small number of medical errors. ${ }^{35}$ Our system, like others in our setting, bases its operation on high quality standards. Although all our actions have the potential to injure others, it is widely considered that childbirth will never be an action whose risks are fully controlled. ${ }^{36}$ Moreover, although scientific advances and improvements in medical care have led to a drastic decrease in risks, they are not correlated with a decreased number of claims generally against physicians, or against physicians in this specific specialty.

Physicians receive little training on the legal and judicial aspects of their professional practice. Perhaps they also receive little information. We would like this paper to be a stimulus for encouraging further studies in this area.

\section{Conclusions}

This paper aims to provide figures for a well-known fact; i.e., that obstetrics involves the highest compensation awards for malpractice, especially for permanent damage related to the foetus, be it cerebral damage related to childbirth or errors in prenatal diagnosis. In gynaecology, claims for errors in diagnosing breast cancer, and rarely some other adverse event, are among the most numerous, include the highest 
compensation awards in case of conviction, and have gone all the way to the Supreme Court of Spain.

\section{Limitations}

Owing to its design, this study excludes cases resolved in courts of first instance and out-of-court settlements; accordingly, there may be a bias towards obstetric events which, as already mentioned, include the most serious cases and involve the highest compensation awards. On the other hand, the analysis of these events could be considered the most interesting.

\section{Conflicts of interest}

The authors declare that there are no conflicts of interest.

\section{References}

1. Danzon PM. Liability for medical malpractice. In: Culyer AJ, Newhouse JP, editors. Handbook of health economics. Amsterdam: North-Holland; 2000. p. 1339-404.

2. Carles M. Responsabilidad por una práctica médica inadecuada: una perspectiva económica. Gac Sanit. 2003;17:494-503.

3. Mira JJ, Guilabert M, OrtízL. Navarro IM, Pérez-Jover MV, Aranaz JM. Noticias de prensa sobre errores clínicos y sensación de seguridad al acudir al hospital. Gac Sanit. 2010;24: 33-9.

4. Llovet JJ. Las reclamaciones judiciales por mala praxis médica. Rev Esp Salud Públ. 1993;67:315-23.

5. Guillen C, Aguinaga I, Guillen F. La medicina basada en la evidencia en el sistema judicial norteamericano. An Sist Sanit Navar. 1998;21:385-8.

6. Gómez-Duran EL, Lailla-Vicens JA, Benet-Travé J, ArimanyManso J. Analysis of obstetrics and gynecology profesional liability claims in Catalonia, Spain (1986-2010). J Forensic Leg Med. 2009;16:301-6.

7. Perea Pérez B, Santiago Saez A, Labajo González ME, Albarrán Juan MI, Sánchez Sánchez JA. Análisis de las consecuencias médico-legales de las reclamaciones judiciales de pacientes. Estudio comparativo de los casos de traumatología, ginecología y obstetricia, anestesia y reanimación, y odontoestomatología. Trauma Fund Mafre. 2009;20:264-8.

8. Perea-Pérez B, Santiago-Saéz A, Labajo-González ME, AlbarránJuan ME, Dorado-Fernández E, García-Martín A. El médico ante los tribunales: análisis de las sentencias judiciales relacionadas con la responsabilidad profesional médica en España. Rev Esp Med Legal. 2013;39:130-4.

9. Arimany-Manso J, Gómez-Durán EL, Barbería-Marcalain E, Benet-Travé J, Martin-Fumadó C. Catastrophic medical malpractice payouts in Spain. J Healthc Qual. 2015;38:290-5. Epub ahead of print.

10. Bixenstine PJ, Shore AD, Mehtsun WT, Ibrahim AM, Freischlag JA, Makary MA. Catastrophic medical malpractice payouts in the United States. J Healthc Qual. 2014;36:43-53.

11. Jena AB, Seabury S, Lakdawalla D, Chandra A. Malpractice risk according to physician specialty. $N$ Engl J Med. 2011;365:629-36.

12. Arimany-Manso J, Gómez-Durán EL, Aubia-Marimon J. Las reclamaciones sobre responsabilidad profesional por especialidades en un escenario diferente al estadounidense. Gac Sanit. 2013;27:89-93.

13. Le risque des professions de santé en 2006 [Internet]. Decisions de justice. Rapport sur les décisions de justicerendues en 2006 (médecins sociétaires du Sou Médical-Groupe MACSF).
Responsabilité, Revue de formation sur le risque médical [consulted Nov 2014]. Available in: http://www.cfef.org/archives/ bricabrac/macsf2006.pdf

14. Baremo para la determinación de indemnizaciones por daños derivados de actividades en el ámbito sanitario [Internet], Madrid, 28 June 2013 [consulted Dec 2015]. Available in: http://static.diariomedico.com/docs/documentos/baremo.pdf

15. Chou MM. Litigation in obstetrics: a lesson learnt and a lesson to share. Taiwan J Obstet Gynecol. 2006;45:1-9.

16. Adinma J. Litigations and the obstetrician in clinical practice. Ann Med Health Sci Res. 2016;6:74-9.

17. García-Ruiz N, Santiago-Sáez A, Albarrán-Juan ME, LabajoGonzález E, Perea-Pérez B. Análisis de reclamaciones judiciales contra obstetras y ginecólogos en España. Estudio específico de la vía penal (1987-2013). Rev Esp Med Legal. 2016;42: 136-41.

18. Williams DG. Practice patterns to decrease the risk of a malpractice suit. Clin Obstet Gynecol. 2016;59:439-46.

19. Hamasaki T, Hagihara A. A comparison of medical litigation filed against obstetrics and gynecology, internal medicine, and surgery departments. BMC Med Ethics. 2015;16:72.

20. Schifrin BS, Cohen WR. The effect of malpractice claims on the use of caesarean section. Best Pract Res Clin Obstet Gynaecol. 2013;27:269-83.

21. Boyle A, Reddy UM. Epidemiology of cesarean delivery: the scope of the problem. Semin Perinatol. 2012;36:308-14.

22. Johnson CT, Choubey V, Satin A, Werner EF. Malpractice and obstetric practice: the correlation of malpractice premiums to rates of vaginal and cesarean delivery. Am J Obstet Gynecol. 2016;214:545-6.

23. Chandra A, Nundy S, Seabury SA. The growth of physician medical malpractice payments: evidence from the national practitioner data bank. Health Affairs, published online May 31, 2005.

24. Studdert DM, Mello MM, Gawande AA, Gandhi TK, Kachalia $A$, Yoon C, et al. Claims, errors, and compensation payments in medical malpractice litigation. $\mathrm{N}$ Engl J Med. 2006;354:2024-33.

25. Arimany-Manso J, Gómez-Durán EL, Bruguera M, Aubia J. Un modelo integral y de gestión directa del aseguramiento de la responsabilidad profesional médica en Cataluña. Med Clin (Barc). 2013;141:300-4.

26. Arimany-Manso J, Esperanza L. Gómez-Durán Reclamaciones por presunto defecto de praxis [Internet]. Seguridad clínica. 2014 [consulted in 2016]. Available in: https: / /www.comb.cat/ cat/professional/responsabilitat/pdf/2014 LlibreSEGURIDADCLINICA.pdf

27. Ward CJ, Green VL. Risk management and medico-legal issues in breast cancer. Clin Obstet Gynecol. 2016;59:439-46.

28. MacLennan AH. A template for defining a causal relation between acute events and cerebral palsy: international consensus statement. BMJ. 1999;319:1054-9.

29. Hankins GDV, Speer M. Defining the pathogenesis and pathophysiology of neonatal encephalopathy and cerebral palsy. Obstet Gynecol. 2003;102:628-36.

30. MacLennan AH, Thompson SC, Gecz J. Cerebral palsy: causes, pathways, and the role of genetic variants. Am J Obstet Gynecol. 2015;213:779-88.

31. Jonsson M, Agren J, Nordén-Lindeberg S, Ohlin A, Hanson U. Neonatal encephalopathy and the association to asphyxia in labor. Am J Obstet Gynecol. 2014;211, 667.e1-8.

32. Hasegawa J, Toyokawa S, Ikenoue T, Asano Y, Satoh S, Ikeda T, et al. Relevant obstetric factors for cerebral palsy: from the nationwide obstetric compensation system in Japan. PLoS ONE. 2016;11:e0148122.

33. Johnson SL, Blair E, Stanley FJ. Obstetric malpractice litigation and cerebral palsy in term infants. J Forensic Leg Med. 2011;18:97-100. 
34. Peters PG Jr. Twenty years of evidence on the outcomes of malpractice claims. Clin Orthop Relat Res. 2009;467:352-7.

35. Castellano Arroyo M, Ferrara SD. La responsabilidad profesional médica en Europa. Rev Esp Med Legal. 2014;40:161-6.
36. Soergel P, Schöffski O, Hillemanns P, Hille-Betz U, Kundu S. Increasing liability premiums in Obstetrics-analysis, effects and options. Geburtshife Frauenheilkd. 2015;75:367-76. 